University of California, Hastings College of the Law UC Hastings Scholarship Repository

Faculty Scholarship

1995

\title{
Truth as Justice Investigatory Commissions in Latin America
}

Naomi Roht-Arriaza

UC Hastings College of the Law, rohtarri@uchastings.edu

Margaret Popkin

Follow this and additional works at: https://repository.uchastings.edu/faculty_scholarship

\section{Recommended Citation}

Naomi Roht-Arriaza and Margaret Popkin, Truth as Justice Investigatory Commissions in Latin America, 20 Law \& Social Inquiry 79 (1995).

Available at: https://repository.uchastings.edu/faculty_scholarship/1175

This Article is brought to you for free and open access by UC Hastings Scholarship Repository. It has been accepted for inclusion in Faculty Scholarship by an authorized administrator of UC Hastings Scholarship Repository. For more information, please contact wangangela@uchastings.edu. 


\section{Truth as Justice: Investigatory Commissions in Latin America}

Margaret Popkin and Naomi Roht-Arriaza

In recent years, Latin American countries have sought to come to terms with prior periods of widespread human rights violations, relying increasingly on investigatory commissions. Investigatory efforts have been undertaken by democratically elected governments that replaced military dictatorships, by UN-sponsored commissions as part of a UN-mediated peace process, and by national human rights commissioners. This article examines truth commissions in Chile and El Salvador, an investigatory effort in Honduras, and a proposed commission in Guatemala. It compares the achievements and limitations of these commissions within the political constraints and institutional reality of each country, focusing on four major goals: the effort to create an authoritative account of the past; vindication of victims; recommendations for legislative, structural, or other changes to avoid repetition of past abuses; and establishing accountability or the identity of perpetrators.

In the past 15 years a growing number of countries have tried to come to terms with periods of widespread human rights violations, during which national institutions failed to address rights abuses. Increasingly, coming to terms has involved the constitution of investigatory commissions, often known as "truth commissions." These may be ad hoc commissions appointed by the executive or by parliament, international commissions under United Nations (UN) or regional auspices, or those operating under a more permanent national structure like an ombudsman's office. Such commis-

Margaret Popkin is a fellow at the Washington Office on Latin America. Naomi Roht-Arriaza is an assistant professor of law at Hastings College of Law, University of California. The authors thank Professor Patty Blum for her insightful comments on an earlier draft. Some material for this article is taken from N. Roht-Arriaza, ed., Impunity and Human Rights in International Law and Practice (New York: Oxford University Press, 1995). 
sions have been constituted in at least 15 countries in the last 20 years. ${ }^{1}$ In South Africa, in Haiti, in Guatemala, the creation of a truth commission tops the list of proposed measures for looking into past abuses. In the Balkans and Rwanda, although attention has focused on an international tribunal, commissions of inquiry were also created to gather the facts needed for subsequent prosecutions. Indeed, the truth commission model has become so well known that it runs the danger of being perceived as something of a panacea rather than as one of a panoply of measures needed to undertake the complex process of coming to terms with the past.

This article looks at several investigatory commissions in Latin America and evaluates what they did, why they did it, and how successful they were at meeting their own stated and implicit goals. We look at the truth commissions of Chile and El Salvador, a "truth commission"-like investigatory effort in Honduras, and a proposed commission in Guatemala. We evaluate the commissions by looking at four major, and overlapping, goals: creating an authoritative record of what happened; providing a platform for the victims to tell their stories and obtain some form of redress; recommending legislative, structural, or other changes to avoid repetition of past abuses; and establishing who was responsible and providing a measure of accountability for the perpetrators. Regarding these objectives, we consider how well each commission has done, which have taken precedence, and why. ${ }^{2}$ Part I sets out the context for the establishment of truth commissions in Latin America, while Part Il talks about the specific commissions. Part III evaluates the way each commission satisfied each of the goals discussed above. Part IV concludes by comparing the goals and exploring why the commissions focused their work as they did.

1. For the most exhaustive list and description to date of truth commissions, see Priscilla B. Hayner, "Fifteen Truth Commissions-1974 to 1994, A Comparative Study," 16 Hum. Rts. Q. 597 (Nov. 1994).

2. It is difficult to assess the "success" of an investigatory commission in meeting these goals, at least in the short term. Its impact on a society and even its success on its own terms may well depend on the passage of time and the accretion of historical memory. Thus the impact of a commission's work may be perceived far differently now than 20 years hence. Moreover, the same constraints and possibilities that arise from the social context and political culture and influence the choices made in setting up a commission are likely to determine the extent of follow-up to it-and may also dictate the limits to its success. Thus it becomes virtually impossible to disentangle these "background" effects from the choices made by the commissions. Still, perhaps a measure of how well the commission met its goals is the extent to which its work ameliorated, or at least altered, these same background conditions.

On the other hand, a "successful" commission may be more a reflection of favorable background conditions than of anything the commission does. In any case, while we recognize that the choices made about the content and method of the work of such a commission are not unconstrained, we believe that such choices exist and that different designs may produce different outcomes even within a similar set of constraints. We hope, therefore, that our exploration may prove useful to those in other countries who are beginning to grapple with the issues of truth and justice in the context of successor regimes or negotiated settlements. 


\section{TRUTH COMMISSIONS IN LATIN AMERICA}

Truth commissions in Latin America have been formed in two kinds of circumstances. In the first, civilian governments have replaced formal or de facto military dictatorships. During the period of military rule, real or perceived government opponents were summarily killed, jailed, and tortured by the security forces and their allies. The scope and severity of human rights abuses led to demands on the new government for an accounting of the human rights violations of the prior regime. Chile and, to a lesser extent, Honduras fit this mold. ${ }^{3}$

In the second scenario, demands for investigation have arisen in the context of a negotiated end to civil wars-wars that were themselves largely an outgrowth of frustration with exclusionary political and economic policies. ${ }^{4}$ Aside from the summary execution, torture, or forced disappearance of those considered subversives, Latin American militaries carried out massacres of peasant communities as part of their counterinsurgency strategy. ${ }^{5}$ By the time these conflicts were settled, a civilian government already existed, but military domination continued and large sectors of the population were still excluded from the political process. El Salvador and Guatemala fit into this category.

In both these scenarios, several factors encourage governments to choose the truth commission as the centerpiece of its efforts to confront the past. First, the need for "truth" is related to the types of violations committed under the former regime or during a period of war. While most people had at least some inkling that human rights violations were occurring, the nature of the violations themselves-especially of disappearances and killings by anonymous "death squads"-entailed secrecy and deniability. The phenomenon of "disappearances" was a particularly nefarious aspect of the military regimes: people were picked off the streets or from their homes, often by armed plainclothesmen, and never seen alive again. The detention was never acknowledged; the only clue family members had of the fate of those disappeared was the periodic appearance, in some countries, of mutilated, often unidentifiable bodies along roadsides. When killings were officially acknowledged, they were dismissed as the work of "subversives" or, at

3. Argentina, not discussed here, also fits into this type of situation. The Argentine truth commission (the Sabato Commission) is discussed in, e.g., Hayner, 16 Hum. Rts. Q., and in International Commission of Jurists, "Human Rights in the World: Argentina, the Truth about the Disappeared," 33 Rev. Int'l Commission of Jurists 1-8 (Dec. 1984).

4. See, e.g., Walter LaFeber, Inevitable Revolutions: The United States in Central America (New York: Norton, 1983).

5. See, e.g., Ricardo Falla, Massacres in the Jungle, Ixcan, Guatemala, 1975-1982 (Boulder, Col.: Westview Press, 1994) ("Falla, Massacres in the Jungle"); Mark Danner, The Massacre at El Mozote: A Parable of the Cold War (New York: Vintage Books, 1994) ("Danner, Massacre at El Mozote"); United Nations, From Madness to Hope: The 12-Year War in El Salvador (Report of the Commission on the Truth for El Salvador) (U.N. Doc. S/25500; New York: United Nations, March 1993) ("UN, From Madness to Hope"). 
best, the lamentable excesses of wartime, even if the victims were civilians with little or no connection to an armed organization. Often, killings took place in rural areas away from news media and on a scale that outside observers found unbelievable. The victims were people marginalized by the dominant culture. ${ }^{6}$ Moreover, the shadowy nature of the killings instilled a climate of fear, suspicion, and social withdrawal. ${ }^{7}$ In addition to official obfuscation and denials, the bodies of those disappeared have never been found, leaving family and friends with no possibility of closure. An accounting became necessary on a personal as well as a historical level.

Second, investigatory commissions shortcut some of the difficulties inherent in using "normal" investigatory channels. Both the courts and the police had been at least complicit in the rights violations, and neither were capable of independent inquiries; indeed, if the judiciary had fulfilled its function, an ad hoc commission would not be necessary. Reforming or creating an independent, capable judiciary is a long-term undertaking. Constitutional provisions and reforms may slow the creation of new courts or the appointment of more independent judges. Assuring courts' independent functioning and revising the substantive and procedural codes under which they operate may take years. In many cases, the appointment of competent judges not associated with the failings of the past awaits the emergence and training of a new generation. The need for scrupulous attention to due process and avoidance of both ad hoc courts and ex post facto application of the criminal laws also limit the government's options. The sheer magnitude of past violations, a dearth of evidence concerning crimes that occurred years earlier, and the unwillingness of witnesses to testify in unreliable courts further complicate the task. ${ }^{8}$ So does the need for rapid resolution while the issue is still high on the government-and public-agenda. These difficulties lead many transitional governments to choose investigatory commissions over other methods to confront the past.

6. In Central America, for example, most killings were of peasants. The El Mozote massacre in El Salvador was a case in point: as many as 1,000 people, mostly children, were killed in December 1981. Contemporaneous eyewitness accounts were rejected by policymakers and much of the news media, who attributed the reports to FMLN propaganda. See Danner, Massacre at El Mozote. In Guatemala, thousands of Indian peasants killed by the armed forces spoke no Spanish and followed indigenous traditions. See Falla, Massacres in the Jungle. Throughour Latin America, governments consistently dismissed reports of gross human tights violations as communist propaganda aimed at discrediting them in international opinion.

7. For a description of the effects of these kinds of terror on sociery, see Jaime MalamudGoti, "Transitional Governments in the Breach-Why Punish State Criminals?" 12 Hum. Rts. Q. 1 (1990); id., "Punishing Human Rights Abuses in Fledgling Democracies: The Case of Argentina," in Naomi Roht-Arriaza, ed., Impunity and Human Rights in Intemational Law and Practice (New York: Oxford University Press, forthcoming 1995) ("Roht-Arriaza, Impunity and Human Rights").

8. Witnesses are often reluctant to testify in courts because they fear reprisals. When state institutions have been notoriously unreliable and unable to protect the victims of human rights violations, far more than a state change in policy will be needed to overcome legitimate fears. See UN, From Madness to Hope 23-24. 
Political constraints on other types of actions, particularly those that more directly challenge the hegemony or institutional integrity of the armed forces, constitute a third factor. Here we must distinguish between the two variants discussed above: pacted transitions and negotiations to end a civil conflict. In both situations the room to maneuver will be limited by the still powerful presence of those responsible for the violations but in different ways. In the first, the new government may perceive (rightly or wrongly) that more drastic measures to prosecute those allegedly responsible for violations or to restructure the offending institutions are not feasible given an unfavorable balance of forces. In the context of settlement of a civil conflict, the same government that committed or encouraged the violations may have to implement steps toward "transition." Thus, domestic demands for accounting have been accompanied by increasing international insistence that governments, even successor governments, must take some action against those responsible for grave human rights violations.9 All these factors make investigatory commissions an attractive option, either as a first step opening the door to other actions or as a relatively cost-free way to meet popular demands for an accounting and then close the book on past violations. While the rhetoric of commissions has highlighted the former conception, the reality has been closer to the latter. The next section describes the commissions established in Chile, El Salvador, Honduras, and the one proposed for Guatemala.

9. Under international law, the successor government is responsible for the acts of the prior regime, even though it in fact had no control over them and often those now in power were victims of the prior government. The law makes no provision for situations where one part of the state, i.e., the military, is not within the effective control of another part. In addition, there is increasing international recognition that states have a duty to investigate, prosecute, and provide some kind of redress for certain grave human rights violations, including disappearances, widespread and systematic summary executions (or other crimes against humanity), and torture. As a corollary, while political crimes are amnestiable under international law, this subset of crimes that must be prosecuted cannot be subject to a blanket preinvestigation amnesty. See, e.g., Diane Orentlicher, "Settling Accounts: The Duty to Prosecute Human Rights Violations of a Prior Regime," 100 Yale L.J. 2537 (1991); Naomi RohtArriaza, "State Responsibility to Investigate and Prosecute Grave Human Rights Violations in International Law," $78 \mathrm{Cal}$. L. Rev. 449 (1990); Inter-American Commission on Human Rights, Commission v. Uruguay, report No. 29/92, 82d Sess., OEA/Ser. L/V/II.82, Doc. 24 (2 Oct. 1992); id., Report on the Situation of Human Rights in El Salvador, OEA/Ser.LN/II.85, doc. 28 rev., 11 Feb. 1994, at 69-77 ("IACHR, Report on Human Rights in El Salvador"); Velasquez Rodriguez case, Inter-Am. Ct. H.R. (ser. C), No. 4 (1988) (judgment). 


\section{THE NATIONAL COMMISSIONS}

\section{A. The Chilean Commission for Truth and Reconciliation (the "Rettig Commission")}

Chile returned to democratic government in March 1990, when President Patricio Aylwin was elected after 17 years of military rule. The process of transition was designed by the military government, which allowed elections in exchange for the political parties' agreement to respect the constitutional structure put in place by the military. Despite the election of a civilian president, the former head of government, General Pinochet, remained as head of the army, a number of Senate seats remained subject to Pinochet's appointment rather than election, and military and judicial structures remained intact. In these circumstances, the new president confronted the problem of human rights violations committed during the military regime: summary executions, forced disappearances, widespread torture, arbitrary detention, and forced exile.

The new government's most important initiative was the creation of the Commission on Truth and Reconciliation..$^{10}$ The commission's mandate was to "clarify in a comprehensive manner the truth about the most serious violations committed in recent years," establishing "the most complete picture possible of these grave events, as well as their antecedents and circumstances," and "to gather evidence that may make it possible to identify the victims by name and determine their fate or whereabouts."11 The mandate to identify individual victims was testricted to cases of death or disappearance, as these were the most serious violations and those consistently denied by the military; the mandate did not extend to torture not resulting in death, which the new president's advisors felt would be too unwieldy an enterprise to be completed within the allotted time. ${ }^{12}$ The commission was also to propose measures for reparations and reinstatement and to recom-

10. The commission was created by Ministry of the Interior Decree No. 355 of 25 April 1990, published in the Diario Oficial (9 May 1990). The Commission was established by presidential decree after opposition parties in the legislature indicated they would oppose a legislative commission.

11. Report of the Chilean National Commission for Truth and Reconciliation 7, trans. Phillip Berryman (Notre Dame, Ind.: Notre Dame Press, 1993) ("Report of the Chilean National Commission"). Several accounts of the commission's work have appeared in English. In addition to the introduction to the English version of the report by Jose Zalaquett, see Jose Zalaquett, "Balancing Ethical Imperatives and Political Constraints: The Dilemma of New Democracies Confronting Past Human Rights Violations," 43 Hastings L.J. 1425 (1992); Jorge Correa S., "Dealing with Past Human Rights Violations: The Chilean Case after Dictatorship," 67 Notre Dame L.R. 1455 (1992); David Weissbrodt \& Paul Fraser, "The Report of the Chilean National Commission on Truth and Reconciliation," 14 Hum. Rts. Q. 601 (1992); Robert Quinn, "Will the Rule of Law End? Challenging Grants of Amnesty for the Human Rights Violations of a Prior Regime: Chile's New Model," 62 Fordham L. Rev. 905 (1994). at 616 .

12. See Correa, 67 Notre Dame L. Rev. at 1473; Weissbrodt \& Fraser, 14 Hum. Rts. Q. 
mend legal and administrative measures to prevent any recurrence of these acts.

The commission, chaired by jurist Raul Rettig, was composed of eight people, including several conservative scholars and jurists considered close to (or at least not opposed to) the military government as well as people with a record of advocacy on human rights. The Commission worked for nine months with a staff of 60 , interviewing thousands of witnesses throughout the country and at embassies abroad. Commission members also made extensive use of the documents and files of domestic and international human rights groups. The work of forensic anthropologists in digging up clandestine cemeteries and, in some cases, identifying the remains for reburial, also contributed to the commission's work. The commission asked for comments from the armed forces or police on evidence implicating them in crimes but received little substantive response.

The commission presented its final, unanimous report in February 1991. President Aylwin accepted the report and, a month later, announced its main findings on national television. He offered a formal apology on behalf of the government for the acts of its agents. The report was reprinted and circulated and widely reported on in the press. Unfortunately, shortly after the report was presented, the assassination of right-wing senator Jaime Guzman shifted media attention and cut short public discussion of further follow-up to the report. ${ }^{13}$ Since that time, it has not been a major topic of public debate, although, as discussed below, the issue of accountability did not completely disappear.

The report included an explanation of the origins of the violations, their nature, and the institutions responsible. It provided individualized information on a large number of victims. It found 1,068 cases of killings by agents of the state, 957 cases of persons detained and disappeared by state agents, 90 killed by violent opposition groups, and 164 cases involving political violence that could not be attributed to any party. In another 614 cases, the Commission could not come to any conclusions due to lack of evidence. The Commission could not establish the fate or whereabouts of most victims, although it assumed those forcibly disappeared had been killed. Nor did the Commission provide information on those individuals who carried out the deaths and disappearances, limiting its discussion to naming the branch of the armed forces, security forces or opposition groups believed to be responsible.

The commission devoted a large portion of the report to the effects of these crimes on the victims, their families, and the larger social fabric. It recommended reparations to the victims of past violations, including both moral and material compensation. A direct outgrowth of the Commission

13. See Weissbrodt \& Fraser, 14 Hum. Rts. Q. at 622; A. Trushin, "Left-Wing Terrorist Faces Trial in Chilean Court," Tass News Service, 10 Jan. 1994. 
was the February 1992 law, which created the National Corporation for Reparation and Reconciliation. ${ }^{14}$ The corporation established a monthly pension for the families of those named in the report, medical benefits (including psychological counseling) for the families, and a subsidy for the high school and college education of the victims' children.

In addition, the Rettig Commission's report called for human rights education for both the military and civilians, especially lawyers and judges; greater judicial independence; and changes in the laws on states of emergency, military jurisdiction over civilians, and criminal procedure generally. It recommended greater adherence to international human rights treaties and standards, including specific changes in domestic law. In addition, it called for the creation of a human rights ombudsman's office. Finally, it called on the government to commemorate the victims through monuments and support for cultural and artistic works.

\section{B. The Salvadoran Truth Commission}

The Salvadoran Truth Commission, in contrast, was based on a negotiated agreement between an undefeated military and an undefeated insurgency. During the 1980s El Salvador was ravaged by a civil war. Unlike countries in the Southern Cone of Latin America where a debilitated or defeated guerrilla movement served as the pretext for dictatorship and state terrorism, the Salvadoran military faced the most effective guerrilla movement in the continent. Because the FMLN had not been defeated and enjoyed substantial support inside $\mathrm{El}$ Salvador as well as international recognition, it was able to negotiate a far-reaching peace accord as the price for ending the war. Nonetheless, the "transition" government was the same government that had fought the war-a situation with profound implications for the Truth Commission.

Another distinguishing feature of the Salvadoran peace process was the unprecedented involvement of international actors, notably the United $\mathrm{Na}$ tions, in the resolution of the conflict and the implementation of the peace accords. ${ }^{15}$ International human rights experts working with the UN played crucial roles in this process. ${ }^{16}$

14. Decreto-Ley 19.123 (8 Feb. 1992).

15. See UN Secretary General Boutros-Ghali, Agenda for Peace, UN Doc. A/47/277, 17 June 1992.

16. Venezuelan jurist Dr. Pedro Nikken was the UN's advisor on human rights during the peace negotiations and is now the UN's Independent Expert on the Situation of Human Rights in El Salvador. He was a member of the Inter-American Human Rights Court which heard and decided the Velasquez-Rodriguez case. Truth Commission member Thomas Buergenthal was president of the Inter-American Human Rights Court during that period. The 1987-88 decision of the Inter-American Human Rights Court was crucial in defining the state's obligation to guarantee human rights, including preventing, investigating, and prosecuting violations. 
Through the negotiations that ended the Salvadoran conflict, several mechanisms were established to overcome impunity and guarantee human rights. In addition to the Truth Commission, these included a commission to purge the military of human rights violators (the "Ad Hoc Commission"), a new Human Rights Ombudsman, the replacement of military security forces with a new civilian police force, and constitutional reforms to increase the independence of the judiciary. Of these, the Ad Hoc Commission was particularly important. Composed of three distinguished Salvadorans, it reviewed the records of the Salvadoran officer corps and recommended the transfer, retirement, or discharge of more than 100 officers implicated in human rights abuses. ${ }^{17}$

During the negotiations, the parties presented various proposals to end impunity, including lists of well-known cases that should be prosecuted to serve as examples. Unable to agree on the list of cases, the parties ultimately accepted a UN proposal to establish a "Truth Commission" to determine the official truth about the most "important acts of violence" that occurred during the war. The parties recognized the need to make the complete truth known and to "put an end to any indication of impunity on the part of officers of the armed forces particularly in cases where respect for human rights is jeopardized." 18 The government and the FMLN agreed to provide full cooperation, as well as to carry out the commission's recommendations. ${ }^{19}$

The commission's mandate was to investigate "serious acts of violence that occurred since 1980 and whose impact on society urgently demands that the public should know the truth." It was to take into consideration the "exceptional importance that may be attached to the acts to be investigated, their characteristics and impact, and the social unrest to which they gave rise" as well as the need to build confidence in the positive changes being promoted by the peace process. It was also to recommend legal, political, or administrative measures to prevent the repetition of the kinds of acts that occurred in the past and initiatives to promote national reconciliation.

The negotiators agreed that the Truth Commission would be headed by three individuals appointed by the UN Secretary General. Because of the extreme polarization of Salvadoran society, the parties ultimately agreed to entrust this task to foreigners. After consultation with both parties, the UN Secretary General named former Colombian president Belisario Betancur,

17. The exact number of officers involved only became known when the UN published a letter from the UN Secretary General to the Security Council. UN Doc. S/25078, 9 Jan. 1993.

18. Chapultepec Agreements between the Government of El Salvador and the FMLN, ch. 1, "Armed Forces," sec. 5, "End to Impunity," in United Nations, El Salvador Agreements: The Path to Peace (San Salvador: United Nations Department of Public Information No. 1208-92614, July 1992) ("UN, Path to Peace").

19. UN, Path to Peace, Truth Commission Agreement, Undertaking by the Parties, at 31. 
former Venezuelan foreign minister Reinaldo Figueredo, and U.S. law professor Thomas Buergenthal to the Truth Commission. For the first time, an inquiry commission of this kind was UN-sponsored. To protect the commission's independence, both in reality and in appearance, all funds and staff came from outside El Salvador. ${ }^{20}$

The Truth Commission undertook to establish the facts about the violence that occurred in El Salvador during 12 years of war. With a six-month mandate to carry out its enormous task, the commission could only selectively investigate some of the tens of thousands of cases that occurred during the war. The Commission received more than 2,000 testimonies about violations involving more than 7,000 victims. It focused on a smaller universe of particularly important or representative cases. In addition to interviewing victims and survivors, it also interviewed military men of all ranks, FMLN members, lawyers and court personnel, government officials and employees. It collected information from a variety of sources including human rights groups inside and outside El Salvador, and Salvadoran institutions as well as foreign governments and agencies.

The commission published the results of its investigation in 32 cases. In roughly half those cases, the commission found sufficient evidence to name individuals found to have committed, ordered, or covered up the acts investigated. Some 40 military officers were named, most of whom were no longer in active service. Six leaders of the Peoples Revolutionary Army (ERP, one of the five component organizations of the FMLN) were named as responsible for implementing a policy of killing mayors. Others named included civil defensemen, judges, an army lawyer, and several civilians. The U.S. role was not examined, nor were most of the civilians who financed and planned death squad actions named.

The commission recommended a number of measures to prevent the repetition of abuses and foster national reconciliation. One of the most controversial concerned the judiciary, which the commission found responsible for helping perpetuate impunity. The commission recommended that all members of the Supreme Court immediately resign to hasten the appointment of new justices under a new constitutional formula. In addition, the commission recommended that anyone named in the report be removed from any post in the armed forces, the judiciary or public administration, and that a law be drafted preventing those named from holding public office for at least 10 years. The report also called for a full investigation of private armed groups (death squads), for the creation of a fund for compensation of victims to be financed by earmarking $1 \%$ of foreign aid for this purpose, and for the government to carry out fully the reforms specified in

20. See Douglass W. Cassel, Jr., "International Truth Commissions and Justice," 5 Aspen Inst. Q. 69 (Summer 1993). 
the sections of the peace accords dealing with the armed forces, the police, and the judiciary. ${ }^{21}$

\section{The Honduran National Commissioner for the Protection of Human Rights}

Unlike the prior examples, the Honduran investigation into human rights violations committed by the military was carried out by an individual rather than a commission. Thus, there was no "truth commission," strictly speaking, but the investigation served many of the same functions. ${ }^{22}$ Rather than an initial focus on past rights violations, the Honduran inquiry arose out of a forward-looking attempt to curb new abuses.

During the 1980s, although ruled by nominally civilian governments, the Honduran armed forces were the country's most powerful political actors. Several hundred people disappeared, and others, especially peasant and union organizers, were killed in an attempt to head off the creation of antigovernment insurgencies then flourishing in neighboring countries. In addition, Honduras soon became the main base for the U.S.-backed "contra" war against Nicaragua, further increasing the power of the armed forces. When the war against Nicaragua ended, army power declined and civilian governments began some timid reforms, which gradually gained speed with the 1993 election of Roberto Reina as president.

In 1992, then-President Callejas created an ombudsman's office, known as the Commissioner for the Protection of Human Rights. To guarantee its independence, the commissioner was to be selected by the president from a list provided by a National Reconciliation Commission and could only be removed by a two-thirds vote of that commission. All civil and military authorities were to cooperate with, and could not suspend, the Commissioner's investigations. ${ }^{23}$

21. UN, From Madness to Hope, annex (1 April 1993), at 185-98 (cited in note 5). These reforms included creation of a new civilian police force incorporating a limited number of former FMLN combatants, reduction in the size of the army, dismantling militarized security forces, dismissal or retirement of the worst human rights offenders, and reforms aimed at ensuring greater judicial independence.

22. Hayner, 16 Hum. Rts. Q. n. 9 (cited in note 1), does not include it in her list of 15 truth commissions, noting that it calls on the government to establish a truth commission with greater access to restricted information to investigate the full truth. Nonetheless, because the Honduran effort suggests another model for investigating past violations, we include it here.

23. The commissioner's office was established by Decree-Law 26-92 of 8 June 1992, and its independence was further guaranteed by Executive Decree 6/51-92 of 8 Sept. 1992. The office is responsible for overseeing acts and measures necessary to ensure respect for human rights, investigate violations, and oversee Honduras's compliance with international human rights norms. See Comisionado Nacional de Proteccion de los Derechos Humanos, Los Hechos Hablan por Si Mismos (Tegucigalpa, Honduras: Ed. Guaymuras, 1994) ("Valladares Report"). The report has been translated into English as National Commissioner for Protection of 
Shortly after his election, Commissioner Leo Valladares, responding to demands from human rights and other organized groups, began investigating a pattern of disappearances that had taken place in Honduras from 1980 to 1993, most during the early 1980s. Valladares, a member of the Inter-American Commission on Human Rights, was profoundly influenced by the jurisprudence of the Inter-American Commission and Court requiring investigation and sanction of those responsible for disappearances. ${ }^{24} \mathrm{He}$ justified his efforts on two grounds: First, it was necessary to "know the Truth and do Justice to achieve the needed reconciliation of all Hondurans,"25 because it is impossible to forgive without knowing what happened or who was responsible. Second, investigation was necessary to restore public confidence in state institutions, especially the judiciary.

Valladares found 179 cases of disappearances carried out by the armed forces. He named several members of the army high command and specific units, such as Intelligence Battalion 3-16, as responsible for the practice of disappearances. The court system also came in for criticism for its inaction in the face of the disappearances. The report contains a chronology of disappearances, gleaned from press reports, a list of those who disappeared, and more detailed accounts of 14 representative disappearance cases. It also includes testimony given before the Inter-American Court of Human Rights.

Unlike the Salvadoran commission, the Honduran commissioner examined in detail the international context of the disappearances. He discussed the roles of the Nicaraguan contras, their U.S. advisors, and Argentine military trainers in both engaging in and abetting disappearances. The report published the names of a number of Argentine trainers, as well as providing detailed documents regarding U.S. participation in the anti-Sandinista war waged from southern Honduras. However, Valladares was careful to note that the contras and their backers enjoyed the protection of Honduran officials, thus implicating the state. Nonetheless, the report's recommendations ask for more information from both the United States and Argentina on their role in the events described and suggest identifying and extraditing those former members of the Nicaraguan contras alleged to have been involved in disappearances on Honduran soil.

The commissioner recommended that those apparently involved in the disappearances be tried by the appropriate courts; he provided a list of those who occupied certain military posts during the years involved. In addition,

Human Rights, Honduras: The Facts Speak for Themselves (New York: Human Rights Watch/ Americas and Center for Justice and International Law, 1994) ("Honduras").

24. See Velasquez-Rodriguez case (cited in note 9) (establishing a state's duty to investigate disappearances); Inter-American Commission on Human Rights, Reports No. 29/92 (Uruguay), and No. 24/92 (Argentina), 82d Sess., OEA/Ser.L/V/II.82, Docs. 24, 25 (2 Oct. 1992) (the commission, of which Valladares is a member, holds that there are international law limits to posttransition amnesties).

25. Valladares Report at 9. 
the report recommended investigations of all those judges and magistrates who denied habeas corpus petitions filed by family members of the disappeared, changes in the laws governing detentions, periodic visits of human rights groups to detention centers, creation of a special commission to find clandestine cemeteries, extradition of foreign military advisors or contras involved in disappearances, the separation of military and police functions, civilian control over military intelligence, the institution of human rights education and adhesion of Honduras to several human rights treaties. Finally, it recommended an official apology, compensation, and an official monument to the disappeared.

The report was published in January 1994; excerpts appeared in the local press. In an attempt to both measure and increase pressure for compliance, the commissioner announced that he would be reviewing the recommendations in a year's time to evaluate what action had been taken. $\mathrm{He}$ is now preparing a follow-up report.

\section{The Guatemalan Agreement to Form a Truth Commission}

The problem of impunity has been central to peace negotiations between the Guatemalan government and a 20-year-old guerrilla movement, now known as the Guatemalan National Revolutionary Union (URNG). After years of unproductive negotiations, in January 1994 - under intense pressure to end Central America's only remaining war-the two sides signed a framework agreement designed to lead to the signing of a definitive peace accord by the end of 1994. In March 1994, the parties signed a Global Accord on Human Rights. Point 3 of this Accord, entitled "Commitment against Impunity," states:

3.1 The two sides coincide in that firm action is needed against impunity. The Government will not instigate the adoption of legislative or any other kind of measures aimed at impeding the trial and punishment of those responsible for human rights violations.

In addition, the government pledged to specifically criminalize disappearances and summary executions, to press internationally for their proscription as crimes against humanity, and to avoid trying human rights violators outside the normal court system. ${ }^{26}$

The government further agreed to strengthen the office of the Human Rights Ombudsman, combat the existence of clandestine security forces and

26. Global Accord on Human Rights between the Government of the Republic of Guatemala and the Guatemalan National Revolutionary Unity (URNG), Mexico City, 29 March 1994, UN Doc. A/48/928-S/1994/448, 8 April 1994, reprinted in 1 Verdad $y$ Vida xxv (Jan.-Mar. 1994). 
death squads, not to create new civil defense forces "so long as there is no reason to do so," and to provide special protection for human rights activities and organizations and special help to the victims of human rights violations. However, a government agreement to "continue the cleansing and professionalization of the security forces" is thus far not supported by any mechanism to clean out notorious human rights violators or to place the police under civilian leadership. ${ }^{27}$

As in El Salvador, the accord is to be subject to verification by a UN Observer Mission. Under intense international pressure, in June 1994 the parties agreed to the formation of a truth commission. ${ }^{28}$ The commission's mandate is to "clarify with all objectivity, equity, and impartiality the human rights violations and acts of violence that have caused the Guatemalan population to suffer, connected with the armed conflict." Thus, the commission is to look both at the acts of state and nonstate actors, but it is unclear whether its mandate extends to the thousands of killings and disappearances, especially of students, union leaders, priests, and others, who were not involved in armed opposition. The commission's mandate dates from the "beginning of the armed conflict," which has been interpreted to mean from 1960 to the signing of a peace accord. The commission will have up to one year in which to present its findings.

In the preamble to the truth commission accord, the parties refer to "the right [of the Guatemalan people] to know the whole truth concerning these events, clarification of which will help avoid a repetition of these sad and painful events and strengthen the process of democratization in Guatemala." The commission is to present a report on its findings and recommend measures "to preserve the memory of the victims, to foster a culture of mutual respect and observance of human rights and strengthen the democratic process." However, the commission is not mandated to name individual perpetrators, nor will the report have "judicial aim or effect." The signatories to the agreement also made no commitment to carry out the commission's recommendations.

The UN moderator for the peace negotiations will be one of the members of the truth commission and will name the other two Guatemalan members with the agreement of the parties. One is to be a citizen of "irreproachable conduct" and the other an academic selected from a list of three proposed by the university presidents. The commission is to begin its work

27. As of late 1994, topics relating to the role of the military and constitutional reform remained to be negotiated; however, there was little expectation that these kinds of agreements would be reached. Unlike the Salvadoran military, which while not defeated found itself unable to defeat the FMLN, the Guatemalan military considers itself victorious and has shown little disposition to make concessions.

28. Accord on the Establishment of the Commission to Clarify Past Human Rights Violations and Acts of Violence That Have Caused the Guatemalan Population to Suffer, signed in Oslo, Norway, 23 June 1994, UN doc. A/48/954-S/1994/751, 1 July 1994 ("Accord on the Establishment of the Commission"). 
after a final peace accord has been signed and a cease-fire is in effect. Since the signing of the truth commission agreement in June 1994, further negotiations have stalled. The parties are well behind their ambitious schedule, which called for the peace process to conclude in December 1994, although the UN Observer Mission was put in place in late 1994.

\section{EVALUATION IN LIGHT OF STATED AND IMPLICIT GOALS OF THE COMMISSIONS}

\section{A. Establishing an Authoritative Record}

The first goal that all the commissions set for themselves is to compile and present a historical record of the scope, means, and victims of the prior human rights violations. Presentation of a full and unbiased record was important both to counter the deceptions and justifications of the military and to move fairly recent and still-potent events into the more distant category of "history," establishing a line between past and present. In a politically charged atmosphere, creating an authoritative history is not an easy task. The commissions created their authority through their composition and through the scope and method of investigation.

\section{Composition}

To be successful, investigatory commissions must establish both their independence from all the actors in a contested history and their moral authority to examine and judge the acts and motivations of others. Each of the commissions chose a different route to establishing independence and moral authority. The Chilean commission tried to balance well-known figures from across the political spectrum; it included former ministers of the Pinochet government (although none directly involved in military or security posts) as well as long-time human rights activists. Moreover, the even number of commissioners was intended to maximize the chances of a unanimous outcome. To some extent, this tactic seems to have been successful: even though the armed forces and the political right have disagreed with the commission's analysis, few have challenged the factual basis of its report. On the other hand, human rights activists have noted the timidity of the report, which may also be due to the effort to be "balanced" and maintain consensus, as well as to limits in the commission's mandate. ${ }^{29}$

29. For example, critics noted that the report did not name the names of perpetrators, did not recommend prosecutions, and did not single out the armed forces as having qualitatively different responsibility for human rights violations, as compared with the political parties, the church, and other actors in Chilean society. See Jorge Mera, "Truth and Justice in 
The Salvadoran truth commission tried to ensure both independence and moral authority through the appointment of well-respected foreign dignitaries as commissioners and through prohibiting the use of Central Americans as staff to the commission. Undoubtedly, an international commission has several advantages: distance from domestic political squabbles, a claim to greater objectivity and disinterestedness, a higher degree of protection from reprisals, the clout to publicize its recommendations internationally and to use international pressure to see them implemented. This very distance may, however, prove problematic, giving rise to both a perception and, possibly, the reality that the report is merely a UN document which gives an outside vision of a historical period and contains conclusions that may be discounted rather than being officially assumed. Yet in a situation in which there has not been a change in government and the country remains highly polarized, it may be the only viable alternative.

The decision in El Salvador to have an international commission under UN auspices instead of a commission of national notables had several ramifications. On the negative side, foreigners, especially staff, not immersed in the Salvadoran context may have encountered difficulties in perceiving the relative importance of certain cases as well as the consequences of some of their decisions and recommendations. In contrast to the commissions in the Southern Cone, this process did not bring together diverse national actors to write a common history. The international nature of the Salvadoran commission became a target of attack from quarters dissatisfied with its findings and recommendations who charged that Salvadoran sovereignty had been violated and judicial functions usurped. ${ }^{30}$ Government officials, members of the ruling party and military officers rejected and attacked the report.

Outside the country, however, and in many quarters in El Salvador, UN sponsorship enhanced the commission's credibility. Precisely because they were outsiders, the three commissioners and their staff could ask hard questions and push to get information in a way that would have been difficult for Salvadorans or those closer to the conflict. Their efforts were bolstered by their UN status, which led many people to come forward who had never presented their testimony to national human rights groups. ${ }^{31}$ Despite

the Democratic Government," in Roht-Arriaza, Impunity and Human Rights ch. 12 (cited in note 7) ("Mera, 'Truth and Justice'").

30. The indictment of Truth Commission member Figueredo by Venezuelan courts on charges of corruption related to the government of Carlos Andres Perez gave ammunition to those in Salvadoran society who disagreed with the report's findings. The Venezuelan charges first appeared in the Salvadoran press as the commission's report was about to be published. 31. Thomas Buergenthal, "The United Nations Truth Commission for El Salvador," 27 Vanderbilt J. Transnat'l L. 497, 542 (1994). 
official rejection, a public opinion poll conducted in June 1993 indicated wide acceptance of the Commission's findings. ${ }^{32}$

Honduras used still a third approach: a well-respected individual closely connected to and backed by international connections. Commissioner Valladares gained international recognition and some degree of protection from his status as a member of the Inter-American Commission on Human Rights. He worked closely with several UN advisors but presented his findings as part of a national institution that was itself part of the machinery of government. Although the head of the army was predictably critical, the report was well received by the new president, by official political sectors, and even by a few members of the armed forces, anxious to put the past behind them. It was given wide press circulation. The Honduran solution seems to offer familiarity with local political nuances, less tendency toward timidity in the name of maintaining unity, and some degree of international scrutiny and backing. However, an individual may not carry the same weight as a special or international commission and may find it harder to get his or her recommendations implemented, as we discuss below.

The Guatemalan model foresees a hybrid commission, composed of one international representative and two "notables." It remains to be seen how well this composition will work in a highly polarized situation. ${ }^{33}$ Given the extreme polarization of Guatemalan society and the well-founded fear of military infiltration of other "reformed" investigatory bodies, concerns have been raised that Guatemalan participation in the commission may frighten potential witnesses.

32. The poll, carried out by the Public Opinion Institute of the Central American University (UCA), found that $45 \%$ of Salvadorans questioned were satisfied with the Truth Commission's report, while $27 \%$ were dissatisfied. Three-fourths of those polled favored the removal from office of officials found to have violated human rights. Universidad Centroamericana José Simeón Cañas, Instituto Universitario de Opinion Publica, Boletín de Prensa, Año VIII, No. 2, "La Opinión de los Salvadoreños sobre la Comisión de la Verdad" (1993).

33. National commissions, unless they have strong international backing, may be more problematic in cases of settlement of civil conflicts. For example, the Ad Hoc Commission in El Salvador, created at the same time as the truth commission, was composed of three Salvadorans who reviewed the human rights records of military officers and recommended the transfer or discharge of 102 officers, including most of the high command. Implementation of their key recommendations only occurred after the UN Secretary General stepped in to demand compliance. Without the UN's involvement, they might well have engaged in a futile - and dangerous - exercise. The joint group to examine ongoing death squad activities in El Salvador, formed as a result of one of the truth commission's recommendations, was a combined effort of Salvadorans and UN personnel. Because of the Salvadorans' involvement, a number of organizations and individuals considered it less trustworthy than the truth commission and chose not to share their information with it. 


\section{Scope and Methodology of the Report}

To create authoritative history, a commission's work must be broad enough to cover the principal harms and to focus on the appropriate time period; it must be detailed enough to convince skeptics that the facts found are true, yet must also provide the overall patterns and explanations that shape historical accounts; and it must use fact-finding methods that are understandable and beyond challenge. To some extent, each commission did this, yet each also encountered serious constraints and limits.

Each commission focused on a limited set of crimes: deaths and forced disappearances. These were the worst crimes, and the ones the perpetrators had most often denied. Other crimes, such as the torture of detainees who survived, were treated in much less detail. While justified because of time and staff limits, this exclusion, especially in the Chilean case, was criticized by human rights groups and may have limited the depth of the commission's recommendations in the area of treatment of detainees. ${ }^{34}$ The Honduran investigation was limited to disappearances, because these had been by far the most widespread although not the only serious rights violation, especially during the early 1980s. Moreover, the Honduran commissioner placed great emphasis on the "right to the truth," which required above all an accounting for those whose fate had never been established. ${ }^{35}$

A second, related question concerns the degree to which a commission chooses to focus in depth on a limited number of exemplary cases while listing minimal data for others, as the Salvadoran Truth Commission did, or tries to provide information on a wider range of events. Selective investigation has the advantage of allowing better-researched conclusions about the origins and responsibility for cases chosen but must take care to stress their representative character. Of course, to some degree the choice can only be made in context. While in Honduras it would have lessened the report's credibility if it had not tried to investigate all 179 disappearance cases, surely in El Salvador, with more than 50,000 killed and thousands disappeared, such an undertaking was untenable. The Guatemalan commission will face a particularly difficult challenge because of the extended time period to be examined (over 30 years) and a larger number of victims than in any other Latin American country's recent history. An added difficulty in

34. Several countries where truth commissions operated, including Chile, continue to experience periodic reports of torture of prisoners. On Chile, see Amnesty International, 1993 Report (London: Amnesty International, 1993) (torture and mistreatment of suspects in police custody); on Argentina, see Americas Watch and Centro de Estudios Legales y Sociales, Police Violence in Argentina: Torture and Killings in Buenos Aires 20 (New York: Americas Watch, 1991). On El Salvador, see UN Observer Mission Report of the Director of the Human Rights Division of ONUSAL covering the period 1 March-30 June 1994, UN Doc. A/49/281, 28 July 1994, at para. 66.

35. See Carlos Chipoco, "El Derecho a la Verdad: Un Análisis Comparativo" (presented at 18th Latin American Studies Association Congress, March 1994, Atlanta). 
the Guatemalan case is that most of the victims were indigenous peasant farmers of Mayan descent. It will no doubt be much harder to track down the names and circumstances of death of these people than it would be if most victims were urban and working or middle class.

Part of establishing a credible history is the simple listing of names, dates, and places compiled directly from witnesses and victims' families and indirectly from national and international human rights groups and press sources. Listing names rather than overall numbers precludes accusations of double counting and makes the cumulative horror more real. Relying on primary sources rather than press reports also increases credibility: in that sense the Honduran report, which did little independent investigation, was open to critique.

The main achievement of the Salvadoran commission was the exhaustive investigation of a number of highly publicized and contested cases. The commission's report fixed blame on the army high command (including Defense Minister Ponce) for the 1989 murder of six Jesuit priests, their housekeeper, and her daughter. It credited ARENA party founder Roberto D'Aubuisson with organizing death squads and planning the murder of Archbishop Romero. These findings were long suspected among political circles in El Salvador, but the amount of evidence unearthed by the commission is likely to make its report the definitive version of these events into the future.

None of the commissions succeeded in finding the whereabouts or remains of the disappeared; the meager results were particularly disappointing in Chile, where the commission's mandate explicitly called for it to do so. The main obstacle was the lack of cooperation from the military and the limited power of an ad hoc commission to compel testimony and production of documents. The inability to call hostile witnesses, preserve or obtain documents, and/or visit military or police installations has made it difficult for most investigatory commissions to go beyond descriptions of general patterns.

To some degree, the lack of subpoena powers is a function of official fears that such powers would be useless in the face of military or police stonewalling and would set up an unwanted confrontation; that is, it reflects the general weakness of civilian government faced with a strong and recalcitrant military. A strategy for confronting the general difficulty of obtaining information from reluctant institutional actors is to employ some type of plea bargaining aimed at inducing cracks in monolithic institutions. One possibility, proposed by Chile's Aylwin government but rejected by the legislature, is to allow testimony to be taken secretly, without identifying those involved. ${ }^{36}$ Although keeping the substance of the testimony secret raises

36. See Alexandra Huneeus, "Chile Still Divided over Rights Trials," S.F. Chronicle, 10 Sept. 1993, at A14. 
questions about the procedure's validity as a truth-seeking device, concealing the identity of, or otherwise protecting, those agreeing to provide useful information seems a worthwhile bargain. The Salvadoran commission chose to maintain the confidentiality of those offering information because witnesses in El Salvador still risk reprisals. Likewise, the Guatemalan agreement authorizes confidential testimony.

A final area where the construction of an authoritative history was particularly contested was in the treatment of nongovernmental forces. The Chilean, Salvadoran, and proposed Guatemalan commissions frame their mandate broadly enough to cover both government-initiated or sponsored human rights violations and the violent acts of opponents within the same investigation. In El Salvador the commission had the task of examining the most "serious acts of violence" rather than relying on a legal definition of which acts constitute human rights violations. The Guatemalan agreement calls for the clarification of the "acts of violence that have caused the Guatemalan population to suffer, connected to the armed conflict." 37 In Chile, the Rettig Commission was charged with examining not only state actions but also "kidnappings or attempts on the life of persons committed by private citizens for political purposes." 38

Combining investigation of government acts with those of nongovernmental forces is another strategy for increasing authoritativeness, creating a sense of "balanced treatment" in a highly charged political situation or, for successor governments, avoiding charges of "victors' justice." It may also be compelled by an unfavorable balance of forces, in which the military will brook no scrutiny of its own actions if those of its opponent are not also scrutinized.

Yet the authoritativeness can be illusory, and the result a distortion of the historical record. One danger is that the two types of violence will be seen as functionally equivalent. Thus the cautionary effect on would-be dictators or torturers, and the educational effect on the population in general, will be lost in the notion that "terrible things happen in all wars and are committed by all sides and the only solution is the broadest possible amnesty." This danger appears to have been exacerbated in the Guatemalan agreement which calls for an examination of "acts of violence ... related to the armed conflict." This potentially excludes from its scope many extremely serious human rights violations committed by government forces, such as forced disappearances and extrajudicial executions of those considered political, but not necessarily military, opponents. On the other hand, all acts of violence committed by the guerrillas would presumably be related to the armed conflict.

37. Accord on the Establishment of the Commission (cited in note 28).

38. Report of the Chilean National Commission 6 (cited in note 11). 
Both the Chilean and Salvadoran commissions attempted to avoid these historical distortions by stressing the numerical disparity between the violations attributed to the security forces and those attributed to government opponents. The Salvadoran government apparently expected a report that would hold both parties more or less equally responsible for serious violations in the context of the war and call for a general amnesty in the interests of national reconciliation. Yet the commission's investigation and analysis led it to a different conclusion. Aside from the numerical imbalance-only $5 \%$ of the cases presented to the truth commission were attributed to the FMLN while government forces or paramilitary groups were reported responsible for almost $85 \%$-the Salvadoran state was particularly culpable because it never fulfilled its responsibility to prevent, investigate, and sanction these acts, much less compensate the victims. ${ }^{39}$ The Rettig Commission made similar points, yet was still criticized for characterizing the acts of armed opposition groups as "human rights violations."40

A further danger is that the opposing sides can deflect criticism of their own actions by pointing to "biased" treatment of the other side. The Salvadoran government was highly critical of the commission's treatment of FMLN actions and used the apparent imbalance in treatment to question the commission's overall credibility. ${ }^{41}$ Thus, despite political necessities and the authority-enhancing intent of including nonstate actors within the investigation, the results may prove counterproductive.

\section{B. Redress and the Effect on Victims}

A second major stated goal of truth commissions concerns redress and reconciliation. One aspect is the idea that forgiveness requires knowledge of what is to be forgiven, which has deep roots in morality and religion. ${ }^{42} \mathrm{~A}$ second, already mentioned, is the need to overcome the ostracism, isolation and anger of the victims and their families. In the Salvadoran case, every family had either lost a family member or knew someone who had. In contrast, in Chile, while torture and imprisonment were widespread during the days immediately after the 1973 coup, the total number of victims was at most 5,000 in a larger total population. It was possible for large parts of the

39. UN, From Madness to Hope 175 (cited in note 22).

40. See Mera, "Truth and Justice" (cited in note 29). Mera argues that the designation of human rights violations should be reserved for the state, and that to characterize terrorist or criminal acts of nonstate actors this way is misleading and undermines the educational role of a truth commission's report.

41. See Americas Watch, El Salvador, Accountability and Human Rights: The Report of the United Nations Commission on the Truth for El Salvador 25-27 (New York: Americas Watch, 10 Aug. 1993) ("Americas Watch, El Salvador").

42. See Ignacio Martin-Baro, S.J., "Reparations: Attention Must Be Paid," 186 Commonweal (23 March 1990). Martin-Baro was one of the Jesuit priests later assassinated in El Salvador. 
population, especially the middle and upper classes, to have no contact with victims of human rights violations, to find plausible the military's denials that any such violations were taking place, and to shun those who had presumably "done something" to deserve their fate. ${ }^{43}$

The commissions all tried in part to respond to the needs of victims through recommendations focused on reparations, compensation, and commemorative efforts. Two other aspects of the commissions' work also had a deep impact on their success in fostering a sense of redress for victims: the process of listening to their stories and the presentation of the report.

It may be that from the point of view of redress, the process of compiling the commission's report was as important as the final product. Both the Chilean and Salvadoran commissions spent considerable time and staff resources traveling around the country and listening to victims tell their stories. ${ }^{44}$ To finally have a sympathetic hearing from someone backed either by the government or by an international organization, after years of fruitless petitions to skeptical functionaries, had a powerful effect on victims. ${ }^{45}$ Moreover, the process of providing data, stories, proof from newly discovered clandestine cemeteries, and the like incorporated larger groups of people (families, local villages) in an active process of coming to terms with the past, not simply a spectator's reaction to a finished product. In El Salvador the commission's investigation validated the receipt of reliable information from marginalized peasant communities who had often not been believed in the past. A Guatemalan commission may have a similar effect.

On the other hand, in El Salvador the positive effects of the process were to a large degree offset by the commission's inability to meet the expectations of those who gave testimony. The decision to focus on a smaller universe of cases meant that most of those who testified were disappointed to find that their case was not among those selected for in-depth treatment. The exercise of taking testimony inevitably raises expectations that something will happen as a result - that those responsible will be identified and possibly punished; that victims and their relatives will be compensated; or that, at a minimum, the truth about what happened will be publicly disclosed.

43. See Jaime Malamud-Goti, "Punishment and a Rights-Based Democracy," Crim. Just. Ethics, Summer/Fall, at 7; S. Salimovich, E. Lira, \& E. Weinstein, "Victims of Fear: The Social Psychology of Repression," in Juan E. Corradi, P. W. Fagen, \& M. A. Garreton, eds., Fear at the Edge: State Terror and Resistance in Latin America 72-89 (Berkeley: University of California Press, 1992).

44. In the proposal for a South African truth commission, one of the official objectives listed is to provide victims with a platform on which they can "express their plight and tell their story." This is the clearest recognition to date of the value of storytelling in coming to terms with the past. The bill establishing the truth commission is reprinted in Oxfam South Africa, 43 South Africa Watch (9 Sept. 1994).

45. See Zalaquett, 43 Hastings L.J. at 1437 (cited in note 11). 
In Honduras the "process" effect was limited by the small size of the commissioner's staff and budget. While the Chilean commission hired some 60 staff members and the Salvadoran commission between 20 and 30,46 Leo Valladares worked practically alone. Thus a multiperson commission, and/or one with access to significant funding to hire staff, would maximize the positive effects of involving people in the investigatory process.

Another factor affecting a truth commission's ability to provide redress for victims is the way in which the report is presented and received. Here the Chilean and Honduran cases differed widely from the Salvadoran. In the Chilean case, President Aylwin received the report and, in a televised speech, accepted responsibility as head of the Chilean state for the acts of state agents. He apologized to the victims and announced measures to make amends. In the Honduran case, too, the report was prepared from within existing governmental structures as a way of making clear the state's acceptance of its responsibility; the current president accepted the report and has supported its recommendations. In El Salvador, however, the government never accepted the commission's findings of fact as its own. Public acknowledgment of past events, which many commentators have found to be required for the internal process of coming to terms with the past, ${ }^{47}$ may depend on the government itself accepting the state's responsibility for the past acts. To some degree, representatives of the international community may listen to victims and validate their stories. Yet if the state does not make the commission's conclusions and recommendations its own or publicly accept responsibility for the harmful acts of its agents, an essential part of the process of acknowledgment and subsequent healing may be lost. Thus, it is not simply the compilation of the report that matters; equally important to success with respect to redress for victims is how, and by whom, the report is presented and how the state receives it.

\section{Design and Implementation of the Commissions' Recommendations}

One measure of the effectiveness of a truth commission is the degree to which its recommendations are accepted and implemented. All three commissions recommended changes to prevent repetition of the kinds of widespread human rights violations they encountered: these included adherence to international human rights treaties, decentralization of control over judicial selection and other judicial reform, compensation for victims, and

46. Buergenthal, 27 Vanderbilt J. Transnat'l L., at 504 (cited in note 31).

47. See, e.g., Alice Henkin, "Conclusions," in State Crimes: Punishment or Pardon? (Wye, Md.: Aspen Institute, 1989). Thomas Nagel, a participant in the seminar that gave rise to this book, distinguishes between knowledge, which existed, and acknowledgment, which was the necessary, and missing, factor. 
measures aimed at professionalizing the military and police and at human rights education in general.

-The recommendations differ in their emphasis, however. The Chilean commission focused many of its recommendations on providing reparations to victims, on education in human rights, on bringing Chilean law into line with international law, and on measures to clarify the fate of those disappeared. While the commission did recommend changes in judicial selection, the role of military courts, and criminal procedure, they stopped short of anything approaching a complete overhaul of the system. Many of the recommendations were to study the possibility of changes in the existing order. The Chilean commission's recommendations on compensation were put into effect relatively quickly, as were those on setting up an agency to assist relatives in searching for the disappeared. Others have been transformed into legislative proposals and await action by the Chilean Congress. Some of the judicial reform suggestions have also been acted on, through reforms to the relevant legal codes, for example. However, many recommendations for reform not enacted relatively quickly have slipped into obscurity, as the commission's report disappeared from public debate just days after being released and provided no built-in mechanism for revisiting recommendations unrelated to the continuing search for the disappeared.

The Salvadoran truth commission's recommendations focused to a large extent on immediate judicial and political reform. The differing emphases reflect the two countries' differing history and institutions as well as the political context of the commissions' work. Chile during this century has generally had elected governments, many of which pursued moderately welfare-statist polices; the 17 years of Pinochet's rule were perceived by many as an aberration. Apart from this period, the judicial system-while it certainly favored the propertied classes and was in need of reform-developed a reputation for probity and seriousness. In El Salvador, where dictatorships followed each other in a practically unbroken line, no such institutional legitimacy of government, including the judiciary, ever developed. Thus, rather than redirecting and reforming basically functional institutions, Salvadorans confront a need to totally transform the structure of government. The peace process opened the possibility of undertaking fundamental transformations and the truth commission recommendations sought to promote such changes.

The Salvadoran truth commission's recommendations won little favor in government and military circles. Members of the government's negotiating team insisted that the commission had not done what they anticipated. Those named were not dismissed from public service, nor were steps taken to prohibit them from holding future posts. Most of the constitutional reforms called for to enhance the independence of the judiciary were not approved, and the Supreme Court roundly rejected the commission's findings 
and recommendations. Under $\mathrm{UN}$ prodding the government finally agreed in November 1993 to form a group to investigate death squad killings, a group that was unable to make much headway. As of late 1994, no steps have been taken to establish a compensation fund or a memorial to the victims.

Despite the refusal to accept the report, some recommendations initially rejected have had a significant effect. For example, although the Supreme Court refused to step down before the end of its term, no member of that Court was reelected by the legislature in June 1994.

The breadth of the Salvadoran truth commission recommendations, especially those regarding total revamping of the Supreme Court and barring those persons named in the report from certain offices, made implementation of the recommendations difficult. In addition, the political and economic context in El Salvador did not augur well for swift implementation of reforms. In Chile and Honduras (as of 1993 at least), as in Argentina before them, the incoming governments were headed by politicians with a history of concern for human rights and a mandate for change. ${ }^{48}$ In the Chilean case, that history and mandate were tempered by a keen, perhaps overly keen, sense of the limitations of a civilian government acting in the shadow of a powerful military, but they were nonetheless present. In Honduras, part of the political will came from the desire on the part of much of the governing class to disassociate itself from the unpalatable effects of the Nicaraguan contra war of the early 1980 s.

In El Salvador, in contrast, although the government had formally agreed to implement the truth commission's recommendations, its domestic political mandate was for continuity, with the least number of changes possible to end the war and disarm the FMLN. Some of those implicated by the truth commission, notably former Defense Minister Ponce, were considered crucial to ensuring the success of the peace process. Thus, implementing the truth commission's recommendations-especially when these were perceived as going beyond what was agreed to in the negotiations-was not on the agenda of then-President Cristiani or the governing ARENA party. Moreover, when the recommendations entailed public expenditure, for example, to compensate victims, the two countries were in very different positions. While El Salvador's economy was destroyed by 12 years of war and mismanagement, the Chilean economy was booming, and there were far fewer people to compensate.

To some degree, international pressure has substituted for political will in assuring that the recommendations are carried out. The peace accords

48. See David Pion-Berlin, "To Prosecute or to Pardon? Human Rights Decisions in the Latin American Southern Cone," 16 Hum. Rts. Q. 105 (1994). Pion-Berlin argues that the presidents' political background and will was a decisive factor explaining differences in policy among Chile, Argentina, and Unuguay. We believe structural issues were probably more salient but that these personal differences were nonetheless a factor. 
built in some pressure for compliance by making both sides agree to follow the truth commission's recommendations. Thus, UN verification of compliance with the accords includes the degree to which the government has implemented the recommended reforms. UN sponsorship and international involvement also increased the likelihood that international actors would press for compliance with the Commission's recommendations. Indeed, UN pressure has been behind most recommendations implemented, even those ostensibly required by the peace accords. ${ }^{49}$ These have been primarily the recommendations calling for institutional transformation; those that call for dismissing certain individuals from public service or barring future public service have largely been rejected. Of course, UN pressure is effective mostly because it is backed by the promise of foreign aid or the threat of withholding it. And despite belated compliance with some of the truth commission's recommendations, according to the UN Observer Mission's Human Rights Division, impunity remains the leading human rights problem in El Salvador more than a year after publication of the truth commission report..$^{50}$

The Guatemalan army and government, learning from their Salvadoran counterparts, refused to commit themselves to carrying out the proposed truth commission's recommendations, giving the UN less leverage to insist on compliance.

In Honduras, virtually no action has been taken to comply with its recommendations as the one-year period draws to a close. Moreover, U.S. government agencies have yet to provide requested information in their files. To date, no one has been prosecuted, and the head of the armed forces, implicated in the report, has announced his opposition to its recommendations. The lack of implementation suggests that an investigation carried out solely by an ombudsman may lack the clout of a specific ad hoc commission appointed by the executive or a UN-sponsored effort which is more likely to be backed up by international pressure. Commissioner Valladares has attempted to induce compliance by setting a one-year deadline in which to revisit the recommendations, as a way of rekindling public interest and pressure for change. The inclusion of checkpoints and timetables for compliance within the recommendations of the report may save the Honduran recommendations from the relative public silence that befell the Chilean report, but only if the commissioner and his allies can generate enough international as well as internal pressure for compliance.

49. See Margaret Popkin, "El Salvador: A Negotiated End to Impunity?" in Roht-Arriaza, ed., Impunity and Human Rights ch. 15 (cited in note 7).

50. See ONUSAL, Report of the Director of the Human Rights Division for the period 1 March-30 June 1994, UN Doc. A/49/281-S/1994/886, 28 July 1994. 


\section{Accountability}

A fourth possible area in which to judge the effectiveness of truth commissions is their contribution to establishing individual as well as institutional accountability for past acts. Many, although not all, human tights groups and activists, as well as several international entities, have stressed the importance of justice as well as truth in dealing with the past. ${ }^{51}$ The commissions themselves recognize the link between the two. They have established that link in one of two ways: by naming those individuals found responsible for killings and disappearances within their report or by passing the information on to the court system in the hope that the courts will follow up.

\section{Naming Names}

One way to provide some measure of individual accountability for past violations is to publicize the names of those thought to be responsible for organizing or executing the crimes committed. While public identification is neither a criminal sanction nor a civil one, it can have negative effects on the reputation, career, and political prospects of individuals. The truth commissions identified a number of individuals through the testimony of witnesses or victims but took different approaches to using the information..$^{52}$ The Chilean commission declined to name individuals, on the grounds that only a judicial proceeding could responsibly do so. In the Chilean case, the Commission maintained it had neither the mandate nor the resources to assure due process for individuals who might be named, and left the question of individual accountability for the courts. It did assign institutional responsibility to certain branches of the armed forces for certain crimes..$^{53}$ The Guatemalan agreement also bars naming individuals and leaves unclear the potential role of the courts by stating that the proposed commission's recommendations and report will have no "judicial aim or effect."

51. Amnesty International and Human Rights Watch have issued strong statements demanding individual accountability for serious human rights violations. The UN General Assembly has done the same in the case of disappearances and summary executions. See Declaration on the Protection of All Persons from Enforced Disappearance, G.A. Res. 47/133 (18 Dec. 1992), UN Doc. A/RES/47/133, 12 Feb. 1993; Principles on the Effective Prevention and Investigation of Extra-Legal, Arbitrary and Summary Executions, ECOSOC Res. 1989/65 of 24 May 1989, Annex, ECOSOC Off. Rec. 1989, Supp. No. 1 (1990), endorsed by G.A. Res. 44/ 162 of 15 Dec. 1989, GAOR 44th Sess, Supp. No. 49 (1990). See also Inter-American Commission cases and scholarly articles cited supra in note 9.

52. The Argentine investigatory commission declined to publicly name those identified as perpetrators but passed the information along to the relevant courts. The list of those named was leaked to the press, however, and soon became public knowledge. Most of those named were never tried.

53. The commission's mandate specifically precluded it from exercising judicial functions. Report of the Chilean National Commission 7 (cited in note 11). 
Unlike the Southern Cone official commissions of inquiry, the Salvadoran truth commission focused on assigning individual responsibility for violations through findings of fact. The commission stressed that responsibility should fall not on the institution but on those who committed or ordered violent acts. ${ }^{54}$ The commission reasoned that the peace accords made very clear that the truth commission was created because the full truth must be made known, which necessarily implied naming those responsible. 'Not to name names would reinforce the very impunity to which the parties instructed the Commission to put an end."55 The Salvadoran government opposed the decision to publish the names and engaged in a diplomatic offensive to convince the UN to omit them, or at least to delay publication of the report until after the March 1994 elections. ${ }^{56}$

In explaining its work, the commission emphasized that it was not a judicial or quasi-judicial body, which could determine legal rights or obligations. ${ }^{57}$ The peace agreement authorized the commission to carry out its activities on a confidential basis and use whatever sources of information it deemed useful and reliable. ${ }^{58}$ Perpetrators were only named when multiple sources or witnesses had confirmed their role. ${ }^{59}$ Still, the criteria for naming some names and omitting others at times appeared unclear and thus raised questions about political motivations, especially since the sources relied on were not identified. 60

In large part, the Salvadoran truth commission chose to name names because it concluded that a long tradition of judicial dysfunction and complicity made it unlikely, at least in the short term, that any judicial process would follow its report. Naming those responsible for certain notorious killings seemed an essential first step in breaking a tradition of impunity.

The Honduran report took an intermediate approach. While focusing on the institutional responsibility of the army high command and of certain intelligence or other special units-the most notorious of them now disbanded-it listed the names of those who had headed those units as potential targets of judicial investigation. In addition, the report reproduced written and verbal testimony before the Inter-American Court of Human Rights, which named perpetrators of specific disappearances.

54. UN, From Madness to Hope 4 (cited in note 21).

55. Id. at 25.

56. Americas Watch, El Salvador 12-13 (cited in note 41); Buergenthal, 27 Vanderbilt J. Transnat'l L., at 520-22 (cited in note 31 ).

57. Some critics maintain that the commission's recommendations barring people from holding office are penal sanctions that affect legal rights. This recommendation in particular proved so controversial-and of questionable constitutionality-that it was explicitly rejected by Salvadoran political parties.

58. Truth Commission Agreement, Powers, in UN, Path to Peace 30 (cited in note 18).

59. UN, From Madness to Hope at 24 (cited in note 5).

60. Buergenthal, 27 Vanderbilt J. Transnat'l L., at 518-19, 531-32. 
The authority for an investigatory commission to "name names" became central to the political struggle over the desirability and the scope of the Guatemalan commission. While the army was willing to countenance a commission, it conditioned its acquiescence on the omission of names. The groups composing civil society also focused much of their criticism on this issue, seeing individual accountability as a prerequisite for the report to open the possibility of real change. In contrast to the Chilean case, in Guatemala the justification for omission does not rest on the proper role of the courts - the information obtained is not to be turned over to the courtsbut instead reflects the relative weakness of civil society and the continuing strength of the military in the peace negotiations.

\section{Truth Commissions, Prosecutions, and Amnesty}

An alternative strategy for pursuing accountability as a goal was to turn the names obtained by the truth commission over to the regular courts for subsequent prosecution. This route was contemplated in all three existing commissions (although it may arguably be barred in the Guatemalan case). However, it has proven problematic.

In general, criminal prosecutions for past violations are among the most troublesome issues facing transitional and postwar governments. A few countries, notably Greece after the colonels, post-1983 Argentina, and most recently Bolivia, tried and convicted high-ranking military officers. Ethiopia has begun to try a number of officials of the Menghistu regime, and Hungary has initiated prosecutions of those involved in suppressing the 1956 uprising. In Germany, a few former Communist Party leaders and a number of low-level border guards have been tried. Most countries, however, have encountered obstacles to prosecutions ranging from powerful domestic opposition to inadequate judicial machinery to amnesties and longlapsed statutes of limitations. ${ }^{61}$

All the countries examined here faced limits on attempts to prosecute the military and security forces for the deaths, disappearances, and torture they had been responsible for. The militaries, and their civilian supporters, retained a major share of power and were disinclined to allow legal action against their own.

The accord which established the Salvadoran Truth Commission was designed "without prejudice to the obligations incumbent on the Salvadoran courts to solve such cases and impose' the appropriate penalties on the

61. On the legal difficulties of prosecutions, see Roht-Arriaza, Impunity and Human Rights chs. 3-5, 21 (cited in note 7). On the political aspects, see, e.g., Samuel Huntington, The Third Wave: Democratization in the Late Twentiech Century (Norman: University of Oklahoma Press, 1991); John Herz, ed., From Dictatorship to Democracy (Westport, Conn.: Greenwood Press, 1982). 
culprits." 62 The final article of the agreement establishing the commission stated that "the provisions of this agreement shall not prevent the normal investigation of any situation or case, whether or not the Commission has investigated it, nor the application of the relevant legal provisions to acts contrary to law." Moreover, the parties to the peace accords specifically addressed the issue of ending impunity in the section on the armed forces. ${ }^{63}$

Thus the parties - or at least the peace accords-explicitly recognized the need for prosecution as well as establishing and disseminating the truth about past rights violations. The apparent intent of the negotiators was not to use the truth commission as a substitute for judicial proceedings. ${ }^{64}$

However, despite the language of the accords, both parties had reasons to favor an amnesty. The governing ARENA party, with its historical links to death squads and close allies in the military, argued for a broad amnesty in the name of reconciliation. According to ARENA, attempts to redress past violations would only destabilize the peace process and, in any event, what was at issue were excesses committed during a war in which both sides committed violations. The FMLN never publicly favored an amnesty and refused to discuss the issue during peace negotiations. Nonetheless, it faced the possibility that rights violators connected to or tolerated by the government would escape prosecution while its members could face selective prosecutions in unreliable (unreformed) courts.

The truth commission stopped short of recommending prosecutions because of the unreliability of the existing judiciary. The commission suggested that without a drastic overhaul of the judiciary, prosecutions might be counterproductive and would be unlikely to achieve fair results. The commission was undeniably accurate in its assessment that prosecutions were unlikely and untenable under current conditions. It did not take the opportunity to suggest that certain crimes could not be subject to amnesty on international law grounds. ${ }^{65}$ In choosing not to do so, the commission 18).

62. See Mexico Agreements of 27 April 1991, in UN, Path to Peace 29 (cited in note

63. The Accords state:

The parties recognize the need to clarify and put an end to any indication of impunity on the part of officers of the armed forces particularly in cases where respect for human rights is jeopardized... . All of this shall be without prejudice to the principle, which the Parties also recognize, that acts of this nature, regardless of the sector to which their perpetrators belong, must be the object of exemplary action by the law courts so that the punishment prescribed by law is meted out to those found responsible.

Chapultepec Agreements, ch. 1, "Armed Forces," sec. 5, "End to Impunity," in UN, Path to Peace 53.

64. In contrast, the question of amnesty for the perpetrators of human rights violations was not directly addressed in the peace accords. The two amnesties granted in the wake of the accords are discussed infra at note 66.

65. The Inter-American Commission on Human Rights, on the other hand, has stressed that neither the peace accords nor Protocol II of the Geneva Conventions excuse El Salvador from its obligations under international law, notably the American Convention on Human Rights. See IACHR, Report on Human Rights in El Salvador (cited in note 9). 
appeared to accept that its task had become a de facto substitute for judicial action, despite the contrary language of the peace accords. It left open the possibility of prosecutions in the future once the judicial system was prepared to handle them.

Over the objections of opposition forces, the governing ARENA party pushed through a sweeping amnesty law days after the truth commission report was released. 66 The amnesty law provides for the extinction of civil as well as criminal responsibility. ${ }^{67}$

The UN Secretary General expressed concern about the immediate sweeping amnesty and said that it would have been preferable to have achieved a broad degree of national consensus before approving an amnesty law. ${ }^{68}$ The Inter-American Human Rights Commission was even more critical. ${ }^{69}$ Salvadoran human rights groups unsuccessfully petitioned the Supreme Court to declare it unconstitutional. ${ }^{70} \mathrm{~A}$ public opinion poll carried out by the Jesuit Central American University in June 1993 found pub-

66. Legislative Decree 486, 20 March 1993, published in Diario Oficial vol. 318, No. 56, 22 March 1993. The 1993 amnesty followed an earlier 1992 law. Because of the immediate need to legalize the situation of FMLN leaders who were returning to the country and would be involved in implementing the peace accords, on $23 \mathrm{Jan}$. 1992, the political parties rushed through a National Reconciliation Law. Legislative Decree 147, Diario Oficial vol. 314, No. 14. The agreement amounted to a delayed general amnesty. It excluded from its benefits: (1) persons convicted by juries, to prevent the release of the two officers convicted four months earlier for the killing of six Jesuit priests, their housekeeper, and her daughter; (2) those named in the Truth Commission report as being responsible for serious human rights violations, to allow the Truth Commission to carry out its work before the application of amnesty in all cases. The amnesty law was passed on 23 Jan. 1992; the Truth Commission report was not made public until 15 March 1993.

The same article that provided for these exceptions established that the Legislative Assembly could overrule them six months after the truth commission issued its report. Human rights groups expressed reservations about the law, which permitted amnesty for crimes that cannor be amnestied under international law.

67. The exceptions to the 1992 amnesty were explicitly overruled by the 1993 law and the six-month waiting period for legislative action was eliminated.

68. United Nations, Report of the Secretary General on the United Nations Observer Mission in El Salvador, UN Doc. S/25812/Add. 1, 24 May 1993.

69. See IACHR, Report on Human Rights in El Salvador 69-77 (cited in note 9). The commission concluded that "regardless of any necessity that the peace negotiations might pose and irrespective of purely political considerations, the very sweeping General Amnesty Law passed by El Salvador's Legislative Assembly constitutes a violation of the international obligations it undertook when it ratified the American Convention on Human Rights, because it makes possible a 'reciprocal amnesty' without first acknowledging responsibility (despite the recommendations of the truth commission); because it applies to crimes against humanity, and because it eliminates any possibility of obtaining adequate pecuniary compensation, primarily for victims." Id. at 77 .

70. The nongovernmental Human Rights Commission of El Salvador filed a petition with the Supreme Court on 21 April 1993; Socorro Juridico Cristiano "Archbishop Oscar A. Romero" and the Human Rights Institute of the Central American University filed another petition on 11 May 1993. Both petitions were denied, and the Court ruled that the constitutionality of the amnesty presented a nonjusticiable political question. Resolution of the Petition for Unconstitutionality ("Demanda de Inconstitucionalidad") presented by Joaquín Antonio Caceres Hernández, Sala de lo Constitucional de la Corte Suprema de Justicia, Inconstitucionalidad No. 10-93, 20 May 1993. 
lic sentiment against the amnesty law $(55.5 \%)$, with $77 \%$ of those polled favoring punishment of those who violated rights. ${ }^{71}$ Despite this criticism, the ARENA party seems to have suffered no adverse political consequences from its insistence on a sweeping amnesty or the truth commission's findings that key ARENA members were involved in death squad activities. A year after issuance of the truth commission report, the ARENA party easily won the 1994 presidential, legislative, and municipal elections.

In Chile, the military barred prosecutions through an April 1978 selfamnesty. ${ }^{72}$ The Aylwin government's platform referred to the need to progress toward rescission or annulment of the military's self-amnesty. The presidential decree creating the Commission on Truth and Reconciliation stressed that justice is an additional and separate requirement, affirming that "only on the basis of the truth will it be possible to satisfy the basic demand for justice and create the conditions essential for genuine national reconciliation." ${ }^{73}$ Moreover, article 1 of the decree points out that truthfinding should be understood "without prejudice to any judicial process which may arise from these acts". Article 2 adds that "should the Commission in the exercise of its functions receive information concerning acts of a criminal nature, it will forward it without further ado to the competent court." Nonetheless, the new government declined to challenge the amnesty law.

The commission's report stressed the need for justice in its section on preventive measures.

From a preventive viewpoint, the full exercise by the state of its punitive powers is an indispensable step towards national reconciliation and thus avoidance of any repetitions of these events. Full protection of human rights is only conceivable under the rule of law, which means that all citizens are subject to the law and to the courts of justice. This involves applying the generally applicable norms of criminal laws to those who break the rules that ensure respect for human rights. ${ }^{74}$

In presenting the commission's report, President Aylwin asserted that the commission had turned over the information it gathered to the relevant courts and that the courts would continue to investigate despite the am-

71. Instituto Universitario de Opinión Pública, Universidad Centroamericana José Simeón Cañas, Boletín de Prensa, Año VII, No. 2, 14 July 1993.

72. Decreto-Ley No. 2191 (1978), Diario Oficial, No. 30.042, 19 April 1978. The amnesty applied to all persons who committed criminal offenses between 11 Sept. 1973 (the date of the coup) and 10 March 1978. It excepted individuals currently on trial or convicted, which meant that most government opponents accused of crimes did not benefit. Murder, disappearance, torture, kidnapping, and assault were covered by the amnesty, although other common crimes were not. U.S. political pressure resulted in a specific exemption for anyone involved in the killing of former Ambassador Orlando Letelier and a colleague.

73. Report of the Chilean National Commission at 7 (cited in note 11).

74. Id. at 885 . 
nesty. The "Aylwin doctrine" allowed the ordinary courts to go forward investigating complaints of disappearances, even though the courts would quickly run up against the obstacle of the self-amnesty once they found that the victim had been killed under conditions that implicated the military.

Despite the amnesty, some 200 cases remain before the courts, and another 800 cases, although temporarily closed, could be reopened if new evidence came to light. In the one case specifically exempted from the amnesty, Colonel Manuel Contreras and Brigadier Pedro Espinoza, former heads of the secret police known as DINA, were convicted in 1993 of masterminding the Washington, D.C. assassination of former foreign minister Orlando Letelier and his colleague Ronni Moffitt. They remain free on appeal. ${ }^{75}$ Civilian courts continue to interrogate active army officers in disappearance cases. In addition, families of victims and human rights organizations began a petition drive to force the legislature to nullify the amnesty law. Sympathetic legislators introduced bills to force the courts to interpret the amnesty law narrowly, although none ever came to a vote.

As time went on, the army became increasingly dissatisfied with this state of affairs. In May 1993, the military staged a show of force outside the presidential palace to demand an end to the investigations. The army demanded that the cases be accelerated, and that the hearings, including the questioning of active-duty officers, avoid the creation of "demeaning situations" for the military. In response, several politicians and members of Congress proposed ending the investigations altogether, but the proposal failed in the legislature. President Aylwin reportedly asked the military to publicly acknowledge its responsibility for having wrongfully killed those disappeared and come forward with whatever information it had on the location of their remains in order to end the judicial investigations, but army leaders refused. ${ }^{76} \mathrm{~A}$ bill to appoint additional judges, including military judges, to hear the remaining cases also failed.

Chilean human rights organizations and attorneys have sought unsuccessfully to overturn the amnesty law in the Chilean courts. In 1990, the Supreme Court ruled the amnesty constitutional. ${ }^{77}$ Nonetheless, the courts have continued to hear cases involving military and police abuses during the Pinochet years, with mixed results. One court sentenced three former police officers to life imprisonment, and another three to shorter terms, for the notorious 1985 slaying of three human rights workers, a case not cov-

75. See, e.g., Julia Meehan, "Former Secret Police Chief to Appeal Jail Sentence," Reuters, 13 Nov. 1993.

76. See, e.g., La Nacion (Santiago, Chile), 1 Aug 1993, at 8.

77. Corte Suprema, 24 Aug. 1990, case of Insunza Buscunan, Ivan Sergio (recurso de inaplicabilidad), 87 (No. 2) Rev. de Derecho y Jurisprudencia y Gaceta de los Tribunales, May-Aug. 1990, at 64-86. The Court rejected arguments based on equal protection, on the right to life and on international law, including the 1949 Geneva Conventions and the Genocide Convention. 
ered by the amnesty. Current police chief General Rodolfo Stange was implicated in covering up police involvement in these murders, but refused to resign despite a request from President Eduardo Frei. ${ }^{78}$ In July 1994, a lower court ordered the arrest of another former head of the DINA on charges of kidnapping and illicit association stemming from the forced disappearance of four political activists in 1975 . The court held the amnesty did not apply to kidnapping because the offense continued until the victims' bodies were found. ${ }^{79}$ An appeals court in September 1994 denied a request by secret police agent Osvaldo Romo to have charges against him dismissed under the amnesty law. The court found that the amnesty cannot apply to the killing of prisoners in violation of the Geneva Conventions. ${ }^{80}$

Other cases have fared less well. Charges against several military agents for disappearances were dismissed by the courts under the amnesty law or dismissed by military courts. And the lower court decisions permitting prosecution will eventually be appealed to the Supreme Court which, despite some changes in composition, remains deeply conservative. Under current Supreme Court precedent, once the lower courts discover that the person has been killed and that the military appears to be implicated, the case falls under the amnesty law and must be dismissed. Still, the continuing legal struggle has kept the issue of the amnesty, and of the military's past acts, periodically in the public eye.

In Honduras, the Valladares report referred directly to the possibility of amnesty, declaring that any amnesty must be interpreted consistently with international law: Because the most recent amnesty under Honduran law recognizes Honduras's international obligation to support and protect human rights, Valladares reasoned, an amnesty would be unavailing in cases of disappearances and other violations of fundamental rights. ${ }^{81}$ Therefore, the report recommends that the state undertake administrative as well as judicial inquiries to identify those responsible for disappearances and to try them. Nonetheless, as mentioned above, no prosecutions have been undertaken to date.

In Guatemala, amnesties were passed in 1987 as part of the region-wide Esquipulas peace accords and again in 1991. There is once again talk of an amnesty as part of the peace process, although the government has commit-

78. See "Chile Court Raises 'Cut-Throat' Sentences to Life," Reuters, 30 Sept. 1994; "Chile: Police Chief Cleared of Charges, Re-assumes Post," Inter-Press Service, 17 June 1994.

79. See Gustavo Gonzalez, "Chile: Another Trial Pits Civilian Courts against Military," Inter-Press Service, 12 July 1994; "Chilean Ex-Colonel Arrested in Human Rights Case," Reuters North American Wire, 10 July 1994. Two active-duty army officers were also charged in the case.

80. See "Court Punches Hole in 1978 Amnesty: 'State of War' Argument Backfires on Its Authors," Latin American Newsletters, Ltd. 465, 13 Oct. 1994.

81. Honduras 407-8 (cited in note 23). The report refers specifically to Honduras's obligations under the International Covenant on Civil and Political Rights and the American Convention on Human Rights, which include the right to a fair trial and to judicial protection. See supra notes $9,24$. 
ted itself not to propose such a measure. ${ }^{82}$ While many political leaders rely on the proposition that all sides commit terrible acts during wars and therefore a broad amnesty is called for, key members of the Guatemalan judiciary and Public Ministry are keenly aware of the dictates of international law which do not permit the amnesty of all crimes.

Thus, in El Salvador and Chile, despite the declared intentions of the peace accords and the new government, some measure of truth became in effect a substitute, not a complement, to justice. The Salvador's UN-sponsored truth commission chose to emphasize the unreliability and complicity of the existing judiciary and call for its transformation rather than push for justice in individual cases. Neither the existing judiciary nor the "transition" government of President Cristiani (and now President Calderon) had any interest in pursuing prosecutions or even judicial investigations, nor has the opposition pushed this issue. In Chile, the Aylwin government attempted to use the judiciary as a further truth-finding mechanism, despite the military's self-amnesties, but with limited results in light of military stonewalling and judicial opposition. In Honduras the end result cannot yet be determined, but prosecutions seem unlikely. In Guatemala, the truth commission agreement has been widely interpreted as an attempt to preclude prosecutions, although future events and the yet-to-be-formed commission's interpretation of its mandate remain to be seen. Still, the political and institutional impediments to prosecutions-a weak insurgency and civil popular movement, an intact and victorious army, a government beholden to "institutionalist" army sectors for its support, ${ }^{83}$ a compromised judiciary-are even stronger there than elsewhere in Latin America.

\section{CONCLUSION}

Investigatory commissions have become an increasingly common tool for examining prior periods of widespread human rights violations when state institutions have failed to respond to such abuses. The commissions set themselves four goals-creating an authoritative record; providing redress and a platform for victims; recommending legislative, structural, or other changes; and establishing accountability for the perpetrators. How well have they done?

Perhaps the greatest achievement of these commissions has been the official presentation of an authoritative history, which counters the former regime's account. Although contested by members of the former regime or the armed forces, an authoritative description and analysis prepared by

82. Global Accord on Human Rights sec. 3.1 (cited in note 26).

83. See Trish O'Kane, "Guatemala: 'Moderates' Retain Upper Hand in the Military, Enabling Peace Negotiations to Slowly Move Forward," Notisur-Latin American Political Affairs, 23 Sept. 1994. 
respected national figures across the political spectrum or well-known foreign dignitaries will eventually be widely accepted and form the basis of the historical record. Moreover, a major success of the commissions is their role in listening to, and validating, the stories and the human dignity of the victims. This suggests that it is the process of compiling the commissions' report, as much as the final product, which is important. In other words, it is the involvement of broad sectors of society in providing information and in being listened to that is crucial. If this is true, measures like exhumations of secret grave sites and ceremonial reburials, taking of oral histories and the like, which decentralize the production of history rather than centralizing it in a single commission and its staff, might have similar salutary effects. Nonetheless, the value of the commissions may be their ability to lend an official imprimatur and time frame to the process.

The commissions have done less well at catalyzing structural change and at accountability. Although all the commissions and the institutions that created them stated that ending impunity or providing justice were fundamental objectives, the results have been rather limited. ${ }^{84}$ National commissions have been reluctant to name perpetrators and have been more inclined to turn their findings over to the courts. But the courts have been ill-equipped to handle these cases. Even so, domestic and international pressure for the courts to handle such cases, to interpret amnesty laws narrowly, or to carry out their own investigations may speed the reform process. Moreover, the public attention focused by truth-telling processes on the crimes committed may create a moral and political climate in which prosecutions become more feasible.

After a war in which neither side has emerged as the victor, the calls for prosecution are likely to be muted, particularly if the peace process does not result in a change in government. A government linked to those who committed serious violations in the past is unlikely to favor accountability for past deeds, although it may be willing to accept significant reforms to prevent their repetition. An insurgency which is becoming part of the polit-

84. The Argentine case, which we did not examine, might be considered a counterexample. There, a truth commission (the Sabato commission) produced exhaustive information on some 8,000 disappeared persons. Trials of the commanders of the military juntas followed, with a number of convictions. However, those convicted were eventually pardoned by President Menem after serving little jail time; most of the accused were never tried because of laws limiting prosecutions (the "full stop" law) and creating a conclusive presumption that almost all subordinates were not guilty because they were following orders (the "due obedience" law). Thus, while the truth commission served many useful ends, it is unclear whether an end to impunity can be counted among its achievements. For a thorough analysis, see Alejandro Garro, "Nine Years of Transition to Democracy in Argentina: Partial Failure or Qualified Success?" 31 Coltum. J. Trans. L. 1 (1993); Malamud-Goti, in Roht-Arriaza, Impunity and Human Rights ch. 12 (cited in note 7). 
ical process may view accountability differently depending on its access to power after the peace accords are implemented. ${ }^{85}$

The Salvadoran experience suggests that an external authority fulfills a somewhat different function than does a national commission. While the latter may be better suited to promoting national reconciliation and acceptance by government leaders of the state's role, the former allows some measure of accountability where internal political conditions might not otherwise permit. Those investigatory bodies most willing to focus on accountability seem to be those with strong international backing and international attention-in addition to El Salvador, the former Yugoslavia, and Rwanda UN commissions are the clearest examples.

Moreover, as the Salvadoran experience shows, it takes constant monitoring and pressure-not simply a short-term spotlight-to ensure some measures of compliance with recommendations regarding accountability, even those merely entailing dismissals. It is unclear how many "transitional" situations will be subject to that kind of scrutiny. And international backing and involvement will not alone be enough: they could not, for instance, overcome the strength of the military and the weakness of both the insurgency and civil institutions in the design of the truth commission for Guatemala. There, the Salvadoran experience led the Guatemalan government's negotiators, particularly the military, to make clear that the historical perspective alone was to predominate and to force a design that expressly bars holding individuals accountable.

Thus truth commissions do not bring about transitions to democracy but instead are most useful after such transitions are well underway-once there is considerable consensus on the need to break with the past. Especially as other countries confront their own transitions, there may be a tendency to see in the truth commission model something of a panacea-a way to avoid both enforced amnesia and the piffalls of prosecutions. Certainly the process of listening to the victims, compiling and publicizing the facts, establishing the enormity of the crimes committed and, where achieved, the acceptance of responsibility by the state and by the responsible institutions

85. Thus, a group like the African National Congress (ANC) in South Africa will be more willing to undertake a process that would lead to the identification of those responsible for past violations, including those in its own ranks, than would a former guerrilla force that will have little control over the fate of those identified. In fact, the ANC-led government has proposed creation of a truth commission, which will, in addition to compiling a historical record of crimes committed under apartheid and recommending changes to avoid further abuses, have the power to recommend indemnity from prosecution for individuals who come forward and confess to such crimes. The final decision on whether to grant these pardons will be left for President Mandela. Those members of the security forces or other organized groups who choose not to present themselves to the commission, confess, and seek indemnification will be subject to prosecution. See, e.g., "Mandela Will Grant Amnesty to Some: Waivers for Political Crimes Will Depend on Full Confessions," Chicago Tribune, 8 June 1994, at A6; Lynn Berat, "South Africa: Negotiating Change?" in Roht-Arriaza, Impunity and Human Rights ch. 20 (cited in note 7). 
and individuals, will go some way toward both accountability and reconciliation, especially in situations where more is not possible. Yet it would be a mistake to conclude from this that truth commissions are always a preferable alternative rather than second-best: there are clear limits to their ability to deduce individual responsibilities, to match the perceived solemnity and weight of a properly functioning court, and to compel production of witnesses and information. And, instead of contributing to institution building or encouraging the courts to take action, they may serve to take serious human rights violations out of the sphere of judicial action. Finally, the very justification of the commissions, based on a rhetoric of necessary and painful cleansing of wounds before a fresh start, may raise unrealistic expectations.

The danger is that commissions will be viewed a priori as a substitute for other actions, rather than one of a panoply of initiatives designed to uncover the truth, do justice, and thereby facilitate national reconciliation after a period of dictatorship or repression. Even the best efforts along these lines cannot overcome years or decades of ingrained habits of thought and culture. Far more than a truth commission will be necessary to heal the wounds and create the conditions for a just society. Nor will legal measures alone be able to accomplish these goals. A change in culture, in expectations and in institutions are all required. But with all their limitations, these kinds of measures can play a crucial role in helping to foster a climate in which other necessary changes may take place. 